\title{
PENGEMBANGAN KURIKULUM PENDIDIKAN AGAMA ISLAM DI ERA 4.0
}

\author{
Muhammad Zia Ul Haq \& Tasman Hamami \\ Universitas Islam Negeri Sunan Kalijaga Yogyakarta \\ muhammadzia2904@gamil.com, tasmanhamami61@gmail.com
}

\begin{abstract}
Islamic religious education faces the challenge of distortion in the era of industrial revolution 4.0. The development of digital technology makes it possible for everyone to access all kinds of information and connect quickly through the internet and it's innovation (internet of things). The effects of a positive and negative potential technology for bumans. Islamic religious education must be able to prepare human resources who believe and have morality and become Muslim intellectuals. The development of Islamic education curriculum is an effort in facing challenges in the era of the industrial revolution 4.0. This research uses the library research method by collecting and analyzing library data. The results of the research show that there is a need for adjustments in the curriculum of Islamic education in the 4.0 era. The goal of Islamic education is to make educated Muslim intellectuals. The learning method with a combination of conventional and technology is bleanded leraning. The content of the material must be adapted to the circumstances and skill requirements of the 4.0 era. Evaluation is comprehensive and is a shared responsibility (educational ecosystem). Educators must adjust and have the competencies needed in the 4.0 era. And infrastructure facilities adapted to technological development.
\end{abstract}

Keywords: Development of Curriculum, Islamic Education, Industrial Revolution 4.0

\begin{abstract}
Abstrak : Pendidikan agama Islam menghadapi tantangan distrupsi di era rovolusi industry 4.0. Perkembangan teknologi digital membuat semua orang dapat mengakses segala macam informasi serta terhubung dengan cepat melalui internet dan inovasinya (internet of thing) . Efek dari sebuah teknologi perpotensi postif dan negative bagi manusia. Pendidikan agama Islam harus dapat menyiapakan sumber daya manusia yang beriman dan berakhlak serta menjadi intelektual muslim. Pengembangan kurikulum pendidikan Islam merupakn upaya dalam menghadapai tantangan di era revolusi industry 4.0. Penlitian ini menggunakan metode library research dengan mengumpulkan dan menganalisis data-data kepustakaan. Hsail dari penelitian menunjukan perlu adanya penyesuaian dalam kurikulum pendidikan agama Islam di era 4.0, dari tujuan pendidikan Islam yaitu menjadikan terdidik menjadi intelektual muslim, metode pembelajran dengan perpaduan konvensional dan teknologi yaitu bleanded leraning, isi materi harus disesuaikan dengan keadaan dan kebutuhan skill di era 4.0, evaluasi secara konperhensif dan menjadi tanggung jawab bersama (ekosistem pendidikan). Pendidik harus menyesuiakan dan memiliki komptensi yang dibutuhakan di era 4.0. dan sarana prasarana disesuaikan dengan perkembangan teknologi.
\end{abstract}

Kata Kunci: Pengembanagan Kurikulum, PAI, dan Revolusi Industri 4.0

Islamika : Jurnal Keislaman dan Ilmu Pendidikan

Volume 2, Nomor 2, Juli 2020; 251-275

https:// ejournal.stitpn.ac.id/index.php/islamika 


\section{PENDAHULUAN}

Pendidikan agama Islam dan tantangan era 4.0. Pendidikan Islam berupaya memberikan pengetahuan dan pemahaman tentang ajaran-ajaran Islam yang mengatur, menjelaskan dan membimbing agar di jadikannya cara pandang dan anutan oleh seorang muslim. Pendidikan Islam adalah bagian penting dalam sebuah peradaban manusia agar dapat bertahan dari dinamika perkembangan dan perubahan. Perubahan dan perkambangan bukanlah suatu yang dapat dielakan. Perkembangan pengetahuan dan teknologi dengan tekanan gelobal, menuntut agar merubah cara kerja dan cara pandang masyarakat dunia. Perubahan yang terjadi berupa masuknya era baru atau revolusi industry 4.0 dikenal juga sebagai era digital atau era disrupsi, karena perubahan yang mendasar dan masif tejadi pada masyarakat terhadap bidang teknologi yang mempengaruhi berbagai aspek kehidupan. ${ }^{1}$ Masyarakat dan teknologi telah menyatu dalam kehidupan namun kesiapan dan kedewasan dalam membuat serta memanfaatkan teknologi tidak demikian dibarengi.

Pendidikan diupayakan agar dapat menyelesaikan permasalahan yang dihadapai manuisa sehingga menuntutnya untuk belajar dan berkembang. Dengan pendidikan manusia akan belajar dan berkembang dengan menggali, mengenali, menemukan, dan, memahami segala potensi yang dimiliki untuk dioptimalkan seefektif mungkin sehingga dapat memanfaatkan alam, lingkungan, dan keadaan (peluang) agar dapat bermanfaat bagi dirinya, orang lain dan lingkungannya. Persoalan manusia pada setiap era berbeda beda, begitupula persoalan pendidikan agama Islam di era 4.0 mendapat tantangan besar dengan kemajuan teknologi dalam setiap aspek kehidupan akan memberikan dampak positif dan negative kepada penggunanya. Sehingga dibutuhkan kesiapan sumber daya manusia (pendidik) dan sistem pendidikan yang dapat mempersiapkan sumber daya manusia dalam menghadapainya.

Pendidikan berupaya agar sumber daya manusia dapat berkualitas, alat untuk mewujudkanya berupa kurikulum. Kurikulum merupakan seperangkat pengaturan yang dibuat agar peroses pendidikan dapat berjalan sesuai dengan tujuan pendidikan. Komponen-komponen yang terdapat dalam kurikulum beruapa tujuan, metode, isi/materi, organisasi, dan evaluasi. Dengan kurikulum direncanakan sebagai program

${ }^{1}$ Eko Risdianto, Analsisis Pendidikan Indonesia di Era Revolusi Industri 4.0. (Bengkulu: Universitas Bengkulu. 2019), hlm 2 
pendidikan yang disiapkan untuk pembelajaran siswa. ${ }^{2}$ Kurikulum di Indonesia terus berubah seiring dengan perkembangan negara dan gelobal. Dimulai sejak masa awal kemerdekaan yang masih menggunakan istilah rencana pembelajaran (leer plan) ${ }^{3}$ pada tahun 1947 sampai dengan kurikulum yang saat ini digunakan yaitu kurikulum 2013 (k-13). Perubahan kurikulum sudah terjadi sebanyak 11 kali perubahan yaitu dimulai dari rencana pelajaran 1947, rencana pelajaran terurai 1952, kurikulum 1964, kurikulum 1968, kurikulum 1975 atau MBO, kurikulum 1984 dengan CBSA, kurikulum 1994 dengan suplemen kurikulum 1999, kurikulum 2004 atau KBK, kurikulum 2006 atau KTSP, dan sekarng kurikulum 2013 (k-13). Hal ini menunjukan bahwa Indonesia masih terus berupaya menemukan formula terbaik yang digunakan sebagai alat pendidikan untuk dapat mengambangan sumber daya manusia yang potensial.

Perubahan dan perkembangan kurikulum merupakan dinamika dalam pendidikan. Begitu pula dalam pelaksananan pendidikan agama Islam bukan hanya sebatas pada ranah pemahaman dan melaksanakan kewajiban dalam mengimplementasikan kurikulum saja namun pendidik ditutut untuk dapat mengembangkan kurikulum pendidikan agama Islam dalam perkembngan era revolusi 4.0 yang terjadi, sehingga pendidikan Islam dapat bermanfaat dan dilaksanakan dalam hidupnya sebagai way of life. ${ }^{4}$ Maka pengembangan kurikulum pendidikan agama Islam perlu disiapkan sebaik mungkin sehingga pendidikan agam Islam dapat memberikan nilai-nilai spirit dalam memanfaatkan perkembangan dan perubahan di era distrupsi agar menjadi badan dalam perkambangan yang menghidupkan manusia.

\footnotetext{
${ }^{3}$ Leo Agung, Sejarah Kurikulum Sekolah Menengah Di Indonesia, (Yogyakarta: Ombak, 2015), hlm 22

${ }^{4}$ Aldo Redho Syam, Guru dan Pengembangan Kurikulum Pendidikan Agama Islam di Era Revolusi Industri 4.0, (Jurnal: Tadris vol 14, 2019), hlm 3
}

2

${ }^{2}$ Widodo Winarso, Dasar Pengemabangan Kurikulum Sekolah,(Cirebon: CV. Confident, 2015), hlm 


\section{METODE PENELITIAN}

Penelitian mengguakan jenis penelitian kepustakaan. Metode ini menekankan pada pengunaan data-data yang bersumber dari kepustakaan yang diseleksi serta berhubungan dengan masalah dalam pokok dalam penelitian dan relevan dengan kajian yang diteliti. Kajian memfokuskan pada analisis konten, yakni menganalisis bahan-bahan informasi berupa buku-buku, jurnal, dan bahan-bahan yang berkaitan/relevan secara konperhensif yang didapat dan dijadikan sebagai sumber data, baik permasalahan mangenai pengembangan kurikulum dan permasalahan pendidikan di era 4.0 .

\section{HASIL DAN PEMBAHASAN}

\section{Revolusi Industri 4.0}

Nama istilah industri 4.0 bermula dari sebuah proyek yang diprakarsai oleh pemerintah Jerman untuk mempromosikan komputerisasi manufaktur menurut Yahya. Jerman merupakan negara pertama yang membuat roadmap (grand design) tentang implementasi ekonomi digital. Era revolusi industri ini juga dikenal dengan istilah Revolusi digital dan era disrupsi. Istilah disrupsi dalam Bahasa Indonesia adalah tercabut dari akarnya. Menurut Kasali: Disrupsi diartikan juga sebagai inovasi dari istilah tersebut maka disrupsi bisa diartikan sebagai perubahan inovasi yang mendasar atau secara fundamental, di era disrupsi ini terjadi perubahan yang mendasar karena terjadi perubahan yang masif pada masyarakat dibidang teknologi di setiap aspek kehidupan masyarakat. ${ }^{5}$

Melihat sejarahnya hingga sampai pada revolusi industry 4.0. Dimulai pada akhir abad ke-18 (revolusi industry 1.0) ditandai dengan ditemukannya alat tenun mekanis pertama pada 1784 dengan fasilitas produksi mekanis menggunakan tenaga air dan uap dengan peralatan kerja yang awalnya bergantung pada tenaga manusia dan hewan akhirnya digantikan dengan mesin tersebut, banyak orang menganggur tapi produksi diyakini berlipat ganda. Awal abad ke-20 (revolusi industri 2.0) ketika tenaga uap digantikan oleh listrik dan terciptanya lini produksi masal dapat dibilang industri menjadi komplit. Revolusi industry 3.0 pada awal tahun 1970 dimulai dengan

${ }^{5}$ Eko Risdianto. Analisis Pendidikan Indonesia di Era Revolusi Industri 4.0. (Bengkulu: Universitas Bengkulu. 2019). Hal. 2 
penggunaan elektronik dan teknologi informasi guna otomatisasi produksi dengan kemunculan pengontrol logika terprogram, sistem otomatisasi berbasis komputer ini membuat mesin industri tidak lagi sepenuhnya dikendalikan manusia (beberapa oprator) dampaknya biyaya produksi menjadi lebih murah. ${ }^{6}$ Dan revolusi industry 4.0, diperkenalkan pada tahun 2011 oleh sekelompok ahli dalam berbagai bidang asal jerman dalam acara hannover trade fair lalu secara serius ditanggapi oleh pemerintah Jerman menganai gagasan tersbut hingga pada tahun 2015 Aggella Markel mengenalkan gagasan revolusi industry 4.0 diacara world economic forum (WEF) pada era ini terdapat banyak inovasi baru diantaranya Internet of Things (Io'T), big data, percetakan 3D, Artifical intelligence (AI), kendaraan tanpa pengemudi, rekayasa genetika, robot dan mesin pintar. Inovasi Internet of Things dapat memudahkan dan menghubungkan manusia dengan teknologi, mesin, perangkat, dan sensor melalui jarigan internet. ${ }^{7}$ Menurut Klaus Schwab dalam bukunya The Fourth Industrial Revolution menjelsakan bagimana revolusi industry ke empat ini pada dasarnya berbeda dengan tiga revolusi sebelumnya, terutama pada kemajuan teknologi sebagai ciri utamanya. Fondasi yang mendasari 4IR" (The Fourth Industrial Revolution) lebih banyak terletak pada kemajuan dalam komunikasi dan keterhubungan dibidang teknologi. ${ }^{8}$

Dengna kemjuan teknologi yang menawarkan efektifitas dan efisiensi bisa jadi pendidikan akan berubah darastis. Setiap orang dapat belajar kapanpun dimanapun melalui jaringan internet. Jika orientasi pendidikan adalah untuk mentransfer pengetahun (transfer knowledge) maka akan bermunculan platform-platform belajar yang jauh lebih inovatif dan efisien dibimbing oleh pendidik dengan kompetensi berkuliats pilihan dari pada konvensional, masalah pendidik yang kurang kompetitif dengan perkembangan teknologi tentu menjadi masalah tersendiri juga dalam dunia pendidikan, di era 4.0 itu semua akan tergusur dengan kemjuan teknologi yang pesat namun apakah akan mengantikan sekolah konvensional? Tentu tidak, karena skolah memberikan lingkungan untuk mempersiapakan diri menjadi manusia terdidik (setiap

${ }^{6}$ https:// sevima.com/revolusi-industri-4-0-yang-sudah-di-depan-mata/ di akses pada 14 Juni 2020

${ }^{7}$ https://binus.ac.id/knowledge/2019/05/ menganal-lebih-jauh-revolusi-industri-4.0/ diakses 14 Juni 2020

8 Astrid Savitri, Revolusi Industri 4.0: Mengubab Tantangan Menjadi Peluang di Era Disrupsi 4.0. (Yogyakarta: Genesis, 2019), hlm 64 
ranah baik kognitif, afektif dan psikomotor). Makanya Era revolusi industry 4.0 menuntut pendidikan untuk melakukan redisain atau pengembangan sebagai respone terhadap keadaan ini. Pendidikan dihadapakan untuk menyiapkan sumber daya manusia yang mampu menghadapi persoalan yang dinamis dan pekarjaan-pekerjaan atau propesi baru yang tidak diketahui akan ada (bermunculan). Sejalan dengan hal ini Kementerian, Riset, Teknologi dan Pendidikan Tinggi (Kemenristekdikti) pada acara Rapat Kerja Nasional (Rakernas) menyampaikan perlunya setiap stockholder untuk bersama menyiapkan kebijakan strategis"yang dirumuskan dalam berbagai aspek mulai dari kelembagaan, bidang studi, kurikulum, sumber daya, serta pengembangan cyber university, risbang"hingga inovasi.

\section{Kurikulum Pendidikan Agama Islam}

Kurikulum didefinisikan dari kegiatan oleh raga dan dikembangkan menjadi sebuah pedoman penyelenggaraan pendidikan. Kurikulum secara etimologis di tulis dalam Bahasa Inggris “curriculum” yang diambil dari Bahasa Yunani, yaitu "curir” yang berarti "pelari", dan "curere" yang berarti "tempat berpacu”, Jika melihat dari etimologinya, istilah kurikulum merujuk pada kegiatan olah raga yaitu "pelari dan tempat berpacu atau jalur", 9 secara terminologynya berarti suatu program pendidikan yang memuat bahan pembelajaran, dan pengalaman belajar yang diorganisir, direncanakan dan di rancang secara sistematik berlandaskan norma-norma yang berlaku yang kemudian dijadikan panduan dalam peroses belajar mengajar bagi pendidik dan peserta didik agar tercapai tujuan pendidikan. ${ }^{10}$

Ada beberapa ahli memberikan pengertian kurikulum sebagai rencana pembelajaran dan panduan pemebelajaran. Menurut Hilda Taba yang dikutip Munir mendefiniskan kurikulum sebagai rencana belajar dengan mengatakan, bahwa " $a$ curriculum is a plan for learning". Sama halnya seperti yang disampaiakan oleh Ali, M yang mengkatagorikan pengertian kurikulum menjadi tiga, yaitu: kurikulum sebagai rencana belajar peserta didik, kurikulum sebagai rencana pembelajaran dan kurikulum sebagai pengalaman belajar yang diperoleh peserta didik. ${ }^{11}$ Mac Donald, 4-5

${ }^{9}$ Leo Agung, Sejarah Kurikulum Sekolah Menengah Di Indonesia. (Yogyakarta: Ombak, 2015), hlm

${ }^{10}$ Dakir, Perencanaan dan Pengembangan Kurikulum, (Jakarta: Rineka Cipta, 2010), hlm. 3.

${ }^{11}$ Munir, Kurikulum Berbasis Teknologi Informasi dan Komunikasi.(Bandung: CV Alfabeta, 2010) $\operatorname{hlm} 23$ 
mendefiniskan kurikulum setelah membut subsistem dalam sekolah, yaitu mengajar, belajar, pembelajaran dan kurikulum. Menurutnya kurikulum merupakan sebuah perencanaan yang menjadi panduan dalam peroses belajar mengajar. ${ }^{12}$ Uraian diatas dapat disimpulkan bahawa kurikulum merupakan seperangkat rencana dan pengaturan mengenai tujuan, isi, dan bahan pelajaran serta cara yang digunakan sebagai pedoman penyelenggaraan kegiatan pembelajaran untuk mencapai tujuan pendidikan tertentu. $^{13}$

Pendidikan agama Islam menurut Ahmad Tafsir sebgai sebuah kegaiatan dalam memberikan ajaran Islam atau mendidikan agama Islam, dengan pengertian bahwa pendidikan Islam merupakan nama sistem, dan pendidikan agama Islam adalah usaha-usaha dalam mendidikan agama Islam pada pelajar. ${ }^{14}$ Menurut Muhaimin pendidikan agama Islam adalah bagian dari "pendidikan Islam" dengan beberapa pandangan bahwa pertama, pendidikan menurut Islam yaitu pendidikan yang berdasar Islam atau sistem pendidikan yang berdasar Islam hal ini berarti pendidikan dikembangkan dengan niai-nilai fundamental yeng terkandung pada al-Qur'an dan Hadis. Kedua, pendidikan ke Islaman yaitu setiap kegiatan pendidikan di arahakan pada nilai-nilai Islam, agar menjadi pandangan dan sikap hidup (way of life), dan ketiga, pendidikan dalam Islam yaitu dimaknai bahwa peroses pembudayaan dari pertumbuh kembangan Islam dilihat melalui sejarah uamatnya sejak awal sampai genrasikegenarasi. ${ }^{15}$ Berdasarkan pengertian tersebut kurikulum pendidikan agama Islam terbagi menjadi dua dimensi yaitu pertama, dimensi kurikulum pendidikan agama Islam sebagi rencana dan pengaturan mengenai tujuan, isi dan bahan pembelajaran, dan dimensi kedua, yaitu cara yang digunakan untuk penyelenggraan pembelajaran pendidikan agama Islam. ${ }^{16}$

Pokok ajaran Islam yaitu sebuah upaya bagaimana penganutnya memperoleh kebahagian dunia dan akhirat. Kehidupan dunia dengan segala pedoman yang Islam

\footnotetext{
${ }^{12}$ Muhammad Joko Susilo, Kurikulum Tingkat Satuan Pendidikan Manajemen Pelaksanaan Dan Kesiapan Sekolah Menyongsongnya, (Yogyakarta: Pustaka Belajar, 2008), hlm 80 4

13 Widodo Winarso, Dasar Pengembangan Kurikulum Sekolah,(Cirebon: CV. Confident, 2015), hlm

${ }^{14}$ Ahmad Tafsir, Cakrawala Pemikiran Pendidikan Islam, (Bandung: Mimbar Pustaka, 2014), hlm 2

${ }^{15}$ Muhaimin, paradigma pendidikan islam: upaya mengefektifkan pendidikan agama islam di sekolah, (Bandung: PT Remaja Rosdakarya, 2008), hlm 29-30

${ }^{16}$ KKM NO 183 Tahun 2019 tentang Kurikulum PAI dan Bahasa Arab pada Madrasah
} 
telah mengatur dasar dari segala perbuatan-perbuatan yang manusia sedang atau akan dilakukan, merupakan masa persiapan menuju pencapaian kebahagian yang hakiki. Kehidupan dunia merupakan tempat bercocok tanam, menjalankan amalan-amalan agama sebagai bentuk ibadah seorang hamba, dan memperoleh balasan dari perbuatan dunia kelak diakhirat. Kebahagian akhirat adalah bagian dari janji tuhan terhadap hambanya yang mejalankan ajaran Islam dengn penuh keridhoan, kesabaran, dan penyerahan diri secara kafah serta menjadi sepirit atau kekuatan dalam menjalankan hidupnya di dunia. Bentuk implementasi kesejahteran dunia dan akhirat antara lain (a) aktivitas pendidikan agama Islam tidak dipisahkan dari ibadah, melainkan kesatuan yang terpadu mengenai amal ibadah dalam ihktiar duniawi, (b) oreinatsi dan dorongan belajar terdidik harus diarahkan untuk kebahagian dunia akhirat, (c) praktik pendidikan disekolah/istansi pendidikan harus dijiwai dan diwarnai dengan nilai-nilai agama Islam, ahklak yang mulia dan berbagai bentuk ibadah kepada Allah SWT. Hal ini sejalan dengan kecendrungan masyarakat gelobal yang samakin hedonis, materialistic dan skularistik tanpa diwarnai kehidupan akhirat. ${ }^{17}$ Maka Pendidikan Agama Islam berupaya dalam memberikan pengetahuan dan pemahaman tentang ajaran-ajaran Islam yang mengatur, menjelaskan dan membimbing agar di jadikannya cara pandang dan anutan oleh seorang muslim.

Adapun ruang lingkup ajaran Islam, meliputi Aqidah, Syariah, dan Akhlak (dalam Surat Luqman ayat, 13-19). Akidah yaitu segala yang berkaitan dengan keyakinan atau lebih khusus lagi tentang kimanan (Ilmu Tauhid, Ushuluddin atau Ilmu Kalam), Syariah yaitu segala sesuatu yang mengatur aturan yang berhubungan dengan manusia dengan Tuhan, sesame manusia, dan dengan alam. (Ibdah/dalam rukun Islam dan Muamalah), dan Akhlak yaitu pengajaran yang kaitannya dengan tabiat, tingkah laku dan perbuatannya dengan pondasi norma agama (Akhalak kepada Tuhan, Nabi/Rasul, diri sendiri, keluarga, tetangga, sesama muslim, non-muslim, lingkungan/alam dan lain sebagainya). ${ }^{18}$

Kompetensi yang diperoleh setelah mempelajari pendidikan agama Islam secara integral mencakup dimensi sikap, pengetahuan dan keterampilan. Dimensi

\footnotetext{
${ }^{17}$ Ibid

18 Muhtadin, Pendidikan Agama Islam Pada Perguruan Tinggi, (Jakarta: Mandala Nasioanal, 2016),
} hlm 36-37 
sikap Memiliki perilaku yang mencerminkan sikap: beriman dan bertakwa kepada Tuhan yang maha Esa, berkarakter, jujur, dan peduli, bertanggungjawab, pembelajar sejati sepanjang hayat, serta sehat jasmani dan rohani sesuai dengan perkembangan anak dilingkungan keluarga, istansi pendidikan, masyarakat dan lingkungan alam sekitar, bangsa, dan negara. Dimensi pengetahuan memiliki pengetahuan faktual, konseptual, prosedural, dan metakognitif pada tingkat dasar, teknis, spesifik, detail dan kompleks berkenaan dengan: ilmu pengetahuan, teknologi, seni, budaya dan humaniora. Mampu mengaitkan pengetahuan di atas dalam konteks diri sendiri, keluarga, istansi pendidikan, masyarakat dan lingkungan alam sekitar, bangsa, dan negara. Dan dimensi keterampilan memiliki keterampilan berpikir dan bertindak: "kreatif, produktif, kritis, mandiri, kolaboratif, dan"komunikatif melalui pendekatan ilmiah sebagai pengembangan dari yang dipelajari di satuan pendidikan dan sumber lain secara mandiri. ${ }^{19}$

\section{Tantangan Pendidikan Agama Islam di Era Revolusi Industri 4.0}

Perubahan dan perkembangan merupakan bagaian peroses alami dalam kehidupan. Manusia diberikan potensi akal untuk berpikir terhadap segala persoalanpersoalan hidupnya. Perkembangan teknologi adalah bagian dari perkembangan kemampuan akal manusia dalam memberdayakan dan memanfaatkan segala sumber daya yang telah disediakan. Namun sebuah perkembangan teknologi tidak selalu bebas dari sebuah nilai kemanfaatan tetapi juga membawa dan menyelipkan sebuah pengaruh yang timbul dari mula awal kemanfaatanya (negative effect).

Era 4.0 dikenal juga sebagai era digital atau era disrupsi, karena perubahan yang mendasar dan masif tejadi pada masyarakat terhadap bidang teknologi yang mempengaruhi berbagai aspek kehidupan. ${ }^{20}$ Era 4.0 sangat erat dengan kemajuan teknologi internet, dengannya banyak menwarkan berbagai hal seperti informasi, berita, hiburan, ekonomi, dan lain sebaginya. Hari ini semua itu dapat terhubung dan tersambung ke samua smartphone, kesuama itu juga memiliki potensi yang sama antara untuk kemanfaatan atau penyelewengan/penyalah gunaan. Beberpa platform media hiburan dengan mudah diakses dari smartphone dan tidak jarang bermuatan

\footnotetext{
${ }^{19}$ KKM NO 183 Tahun 2019 tentang Kurikulum PAI dan Bahasa Arab pada Madrasah

${ }^{20}$ Eko Risdianto, Analisis Pendidikan Indonesia di Era Revolusi Industri 4.0. (Bengkulu: Universitas Bengkulu. 2019), hlm 2
} 
hal-hal yang ditidak sesuai dengan norma-norma agama. Sumber informasi yang cepat membuat orang dibelahan dunia dapat mengatahuinya namun begitu banyaknya informasi sehingga setiap orang dapat memberikan persepsi masing-masing akan informasi tersbut bahkan tak jarang informasi tesrsebut dimanipulasi untuk dijadikan sebuah bahan agar saling menghancurkan dan menebar kebencian.

Menurut Amin Abdullah tantangan di era 4.0 yaitu isu kemanusiaan yang berkaitan dengan intoleran, minoritas, diskriminasi, persekusi, friksi dan konflik serta dalam bidang agama mucul tren konservatif. Menurut Dicky Sofiyan dari Indonesian Consortium for Religious Studies (ICRS) ciri konservatisme yaitu (1) seseorang hanya mempercayai pada satu kebenaran, (2) mobilisasai masa, dan (3) mendambakan pemimpin yang kuat. Berbagai macam informasi-informasi, ajaran dan ideology yang datang tersebut tanpa adanya sebuah batasan dan saringan. ${ }^{21}$

Paradigma dalam pendidikan agama Islam terhadap perkembangan industry 4.0 dihadapakan pada dau hal yaitu pragmatis atau preventif. Pragmatis diartiakan bahwa kemajuan teknologi dan inovasi di era 4.0 ini adalah merupakan solusi dan kemudahan untuk mengoptimalkan, mengefektifkan dan mengefisiensikan pendidikan atau kegiatan belajar mengajar dengan mencoba menemukan teknologi yang sesuai terhadap kebutuhan ketercapaian tujuan pendidikan yang sudah ditentukan (era pendidikan 4.0 dengan cyber system) ${ }^{22}$. Sedangkan preventif merupakan padangan bahawa revolusi industry 4.0 dengan segala inovasi dan teknologi yang dibawanya merupakan pisau yang bermata dua, memiliki potensi yang berdampak positif dan berdampak negative. Hal-hal kemungkinan terburuk inilah yang juga menjadi perhatian dan harus diantisipasi oleh pendidikan agama Islam sebagaimana telah dijelaskan tadi oleh Amin Abdullah. Untuk persoalan pemanfaatan teknologi dalam pendidikan ternyata ditemukan masalah yang tidak kalah penting yaitu GAPTEK (gagap teknologi/ melek teknologi), sebagimana hasil survei yang dilakukan oleh KEPALA Pusat Teknologi Informasi dan Komunikasi Pendidikan dan Kebudayaan (Pustekkom) Kementerian Pendidikan dan Kebudayaan (Kemendikbud) Gatot Suhartowo menyebut saat ini dari total guru yang ada di

\footnotetext{
${ }^{21}$ https://jogja.tribunnews.com/2019/04/23/era-industri-40-menjadi-tantangan-bagipendidikan-agama? Diakses 20 Mei 2020

22 https://www.google.com/amp/s/aceh.tribunnews.com/amp/2018/11/27/menjadi-guruera-pendidikan-40 diakses 14 Juni 2020
} 
Indonesia, baru 40 persen yang melek dengan teknologi informasi dan komunikasi (TIK). Selebihnya, masih 60 persen guru masih gagap dengan kemajuan di era digital ini. $^{23}$

\section{Pengembangan Kurikulum PAI di Era Revolusi Industri 4.0}

Kurikulum pada dasarnya bersifat dinamis, hal ini disebabkan karena pada rentang waktu terjadi perubahan kebutuhan dan perkembangan pada tataran masyarakat (social, budaya, ekonomi, politik, logika gelobal, dan lain sebagainya). Oleh karenanya dilakukanlah pengembangan kurikulum, pengembangan kurikulum diartikan sebagai sebuah usaha menemukan pengaturan dan rencana tentang tujuan, isi, dan bahan pelajaran yang digunakan sebagai pedoman pelaksanan pembelajaran yang sesuai dengan perkembangan dan kebutuhan. ${ }^{24}$ Seprti yang telah disampaikan seblumnya bahwa kebutuhan manusia mengalami perubahan sejalan dengan pertumbuhan dan perkembangan pengetahuan, sehingga pendidikan harus menyiapkan instrument yang tepat untuk memenuhi kebutuhan tersebut. Hal ini seprti yang diungkapkan Alexander Inglis dalam bukunya principle of secondary education bahwa fungsi dari kurikulum sebagai penyesuaian dan persiapan. Penyesuaian yaitu agar dengan pendidikan dapat beradaptasi pada lingkungan masyarakat yang berubah dan dinamis, dapat menjalankan tugasnya sebagai individunya serta dalam anggota masyarakat. Persiapan dartikan bahwa peserta didik dapat untuk mengembangkan jenjang pendidikannya ketahap selanjutnya atau merupakan bekal dalam memasuki dunia kerja dan ini juga yang diperhatikan para pengembang kurikulum. ${ }^{25}$ Pengambangan kurikulum menurut Dakir merupakan peroses menuntun kurikulum yang berlaku kearah tujuan pendidikan yang diinginkan karena adanya pengaruh positif'yang terjadi dari luar atau dari dalam sendiri, dengan harapan terdidik dapat menghadapi"perubahan (masa depan) dengan baik. ${ }^{26}$ Jadi dapat disimpulkan bahawa pengambangan kurikulum merupakan peroses penyesuaian dalam kegiatan

${ }^{23}$ http://jejakrekam.com/2019/03/19/hasil-survei-pustekkom-60-persen-guru-di-indonesiagagap-teknologi-informasi/ diakses 21 Oktober 2019

${ }^{24}$ Widodo Winarso, Dasar Pengembangan Kurikulum Sekolah,(Cirebon: CV. Confident, 2015), hlm 1

25 Abdullah Idi, Pengembangan Kurikulum Teori dan Praktik, (Yogyakarta: Ar-Ruzz Media, 2013), hlm 211-216

${ }^{26}$ Dakir, Perencanaan Dan Pengembangan Kurikulum, (Jakarta: Bumi Aksara, 2010), hlm 91 
pendidikan yang akan diberikan kepada terdidik dengan memperhatikan kebutuhan, perubahan dan perkembangan yang terjadi di masayrakat secara dinamis.

Dalam melakukan pengamabangan kurikulum perlu memperhatikan beberapa hal sebagai langkah pengembangan hal ini disampikan Ralph Tyler yaitu pengembangan kurikulum dalam perosenya dapat menjawab pertama, tujuan pendidikan mana yang mau dihasilkan oleh satuan pendidikan?, kedua pengalaman pembelajaran yang bagimana mau diberikan kepada terdidik yang sekiranya dapat mencapai tujuannya?, ketiga seprti apa pengalaman belajar yang diorganisir secara efektif?, dan kempat bagaimana menentukan tujuan tersebut tercapai?. Hal yang sama di ungkapkan oleh Sukmadinata yaitu dalam langkah pengembangan kurikulum memperhatikan "instructional"objective, selection of learning experiences," organization of learning experiences, and"evaluating". ${ }^{27}$

Adapun beberapa komponen yang termuat dalam kurikulum jika dijabarkan dengan melihat ketentuan yang telah dikemukakan yaitu sebagai berikut: Pertama Tujuan adalah sebuah patokan yang jelas tentang apa yang direncakan, diusahakan, dan dijalankan. Menurut David Pratt memeberikan pendapat tantang tujuan yaitu "six main criteria's may be applied to curriculum aim. Aim should: 1) specify an intention, 2) identify a significant intended change in the learner, 3) be concise, 4) be exact, 5) be complete, 6) be acceptable. ${ }^{28}$ Tujuan yang ingin dicapi dari kurikulum haruslah jelas, mengidentifikasi hal-hal penting sebagai bakal merubah pelajar, ringkas dan jelas, tepat sasaran, menyeluruh dan dapat diterima. Kurikulum sebegai seperangkat pengaturuan dan perencanan agar segala tujuan pendidikan dapat tercapai memuat beberpa tujuan seperti: Tujuan Pendidikan Nasioanal, untuk mengembangakan potensi peserta didik supaya menjadi orang yang beriman dan bertakwa kepada tuhan yang maha Esa, berahlak, berilmu, mandiri, cakap, kreatif, sehat jasmani dan rohani serta menjadi warga negara yang demokratis serta bertanggung jawab. Hal ini berdasarkan falsafah Pancasila. Tujuan Institusional, yaitu tujuan yang dicapai dari setiap jenjang institusioanal seperti pada jenjang SD/MI, SMP/MTs, SMA/MA, dan Perguruan Tinggi. Tujuan Kurikuler, merupakan tujuan yang ingin dicapai setelah siswa

\footnotetext{
${ }^{27}$ Nana Syaodiah Sukmadinata, Pengembangan Kurikulum Teori Dan Praktik, (Bandung: PT Remaja Rosda Karya, 2014), hlm 163

28 David Pratt, Curriculum Design And Development, (USA: Harcourt Brace Javanovich Publisher, 1980), hlm 147
} 
menyelesaikan setiap mata pelajaran. Tujuan Instruksioanal, adalah tujuan yang diharapkan dikuasai oleh siswa ketika mereka mempelajarai pembahasan tertentu dalam salah satu mata pelajaran. Kedua, Isi atau materi adalah bahan yang digunakan dalam pembelajaran harus sesuai dan dapat menunjang ketercapain tujuan pendidikan. Maka dalam menyusuan dan merancang materi yang akan menjadi bahan pembelajaran hendaknya memperhatikan hal-hal berikut: Proporsi, materi yang gunakan dalam pembelajaran tidak berlebihan dan tidak kekuarangan. Relavan, materi yang diajarkan tidak terlalu melabar sehingga jauah dari tujuan yang hendak dicapai. Isi kurikulum mengandung aspek ilmiah telah melalui peroses penelitian dan dapat diterima secara keseluruhan tentang nilai kebenaran. Sistematis, isi atau materi harus runtun pembahasanya tanpa menumpang tindih kronologi keilmuanya (jika dalam materi sejarah maka dipelajari dari urutan waktu kejadianya). Dan materi dapat menunjang ketercapaian tujuan pendidikan. Isi atau materi pengajaran bukan sekedar informasi atau sekumpulan pengatahuan, namun juga harus terdiri dari satu kesatuan pengetahuan yang utuh dan teruji untuk diajarkan serta disesuaikan dengan siswa dan lingkunganya. ${ }^{29}$ Ketiga, Strategi Pelaksanaan Kurikulum merupakan rencana agar bagimana implemantasi dari kurikulum, baik kaitannya dengan perencanaan pembelajaran, metode yang digunakan untuk mengajar, perangkat pembelajaran yang disiapkan, dan pemanfaatan berbagai sumber daya dalam pembelajran sehingga dapat tercapainya tujuan yang di inginkan. Dan Kemapat, Evaluasi merupakan suatu kegiatan pengontrolan, penjaminan, dan pemastian mutu kurikulum, dengan berdasar pertimbangan serta keriteria-keriteria yang telah ditentukan sebagai pertanggung jawaban pengmbang kurikulum guna menentukan keefektifan kurikulum. ${ }^{30}$ Melalui kegiatan evaluasi dapat diketahui sejauh mana peroses yang telah direncanakan dan dilaksanakan tersbut sudah sesuai dengan tujuan perencanaan atau tidak serta akan manjadi bahan kajian terhadap factor-faktor apa saja yang menentukan keberhasilan dan penghambatnya.

Pengembangan kurikulum dilakukan dalam upaya menemukan formulasi yang terbaik dalam mengatur dan menetapkan serangkaian rencana mengenai tujuan,

\footnotetext{
${ }^{29}$ Nana Syaodih Sukmadinata, Pengembangan Kurikulum Teori dan Praktek, (Bandung: Remaja Rosdakarya 2002), hlm 127

30 Zainal Arifin, Konsep dan Model Pengembangan Kurikulum, (Bandung: Remaja Rosdakarya, 2012), hlm 21
} 
materi dan bahan pelajaran yang akan menjadi panduan dalam kegiatan pembelajaran agar tercapai tujuan pendidikan tertentu. Jika melihat undang-undang pendidikan no 20 tahun 2003 tentang system pendidikan nasioanal pada bab X dijelaskan bahwa dalam pengambangan kurikulum harus merujuk pada standar nasional pendidikan agar terwujud tujuan pendidikan nasional. Tujuan pendidikan nasional jika mengacu pada undang-undang pendidikan no 20 tahun 2003 pada bab II pasal 3 menjelasakan bawa tujuan pendidikan nasioanal yaitu untuk mengembangakan potensi peserta didik supaya menjadi orang yang beriman dan bertakwa kepada tuhan yang maha Esa, berahlak, berilmu, mandiri, cakap, kreatif, sehat jasmani dan rohani serta menjadi warga negara yang demokratis serta bertanggung jawab.

Pengambangan kurikulum pendidikan agama Islam, di era 4.0 sangat penting agar dapat mempersiapkan sumber daya manusia yang berpikir dan bersikap moderat, inklusif, berbudaya, religius serta memiliki kemampuan hidup sebgai pribadi yang beriman, bertaqwa, berahklak mulia, kreatif, produktif, inovatif, dan kolaboratif serta dapat memberikan kontribusi dalam menyelesaikan persoalan kehidupan bermasyarakat, berbangsa bernegara, dan peradaban dunia. ${ }^{31}$ Berdarkan dari pendapat Widodo Winarso bahwa kurikulum bukan sebatas mata pelajran saja, namun berkaitan juga dengan segala sesuatu yang dapat mempengaruhi perkembangan siswa, sperti bagunan sekolah, alat pelajaran, perlengkapan, perpustakaan, atau dengan kata lain sarana pra sarana yang menunjang pembelajaran untuk perkembangan siswa. Lebih lanjut lagi dijelaskan tentang kurikulum dengan mengutip pendapat Romine $\mathrm{dkk}$ "curriculum is interpreted to mean all of the organized courses, activities, and experience which pupils have under direction of the school, whether in the classroom or not". Kegiatan kurikulum juga menaungi segala aktivitas dalam dan diluar kelas, jadi pembelajaran tidak memisahkan kegiatan intra dan ekstra karena jika dapat memberikan pengalaman belajar adalah hakikatnya kurikulum. ${ }^{32}$ Maka jika diuraikan langkah pengembangan kurikulum di era 4.0 adalah sebagai berikut:

${ }^{31}$ Keputusan Menteri Agama Republik Indonesia Nomor 183 Tahun 2019, hlm 9

32 Widodo Winarso, Dasar Pengembangan Kurikulum Sekolah,(Cirebon: CV. Confident, 2015), hlm 
1. Tujuan Pendidikan Agama Islam 4.0

Tujuan perlu disesuaikan dengan tantangan yang tegah dihadapi dan pergulatan kemjuan dan perkembangan zaman. Tujuan Pendidkan Agama Islam yaitu untuk mendidikan ajaran agama Islam agar menjadi pedoman/anutan dan pandangan hidup seseorang muslim. ${ }^{33}$ Namun untuk sebuah perkembangan seperti penelitian Sutrisno tentang Pendidikan Islam Yang Menghidupakan, tujuan pendidikan dengan menganalsis pemikiran Fazlur Rahman, bahwa tujuan pendidikan secara khusus adalah agar mengambangkan manusaiasedemikian rupa sehingga seluruh pengetahuan yang diperolehnya akan menjadi organ pada keseluruhan pribadi yang kritis dan kreatif. Kemuidan tujuan secara umum memungkinkan manusia dapat memanfaatkan sumber-sumber alam untuk kebaikan uamat manusia dan dapat menciptakan keadilan, kemajuan, dan keteraturan dunia serta pada titik keimpulannya tujuan pendidikan Islam agar membuat seseorang muslim menjadi intelektual muslim. ${ }^{34}$ Maka tujuan pendidikan agama Islam yaitu menjadikan ajaran Islam menjadi jiwanya, dan semangat hidupnya atau way of life dalam berpikir, bertindak dan bersikap serta menjadi bagain atau badan dalam kemajuan perkembangan dan peradaban umat.

2. Isi dari kurikulum pendidikan agama Islam

Pengembangan pada tahap materi pada pendidiakan agama Islam harus disesuaikan dengan perubahan dan perkembangan zaman, banyak penemuan-penemuan teknologi yang akan bermunculan. dan akan sampai pada suatu titik dimana penamuan tersbut akan berbenturan dengan norma yang ada. Kurikulum pendidikan Islam juga merupakan serangkaian mata pelajaran yang memuat pelajaran al-Qur'an Hadits, Sejarah Kebudayaan Islam, Fiqih, Akidah Akhlak, dan Bahasa Arab. ${ }^{35}$ Dalam pengembangannya, terkait dengan persoalan yang sedang terjadi

${ }^{33}$ Hajar Dewantoro, Pengembangan Kurikulum Pendidikan Agama Islam, (Jurnal: JPI FIAI, Vol 9, 2003), hlm 49-50

34 Sutrisno, Pendidikan Islam Yang Menghidupkan, (Yogyakarta: Kota Kembang, 2008) hlm 105 Lulusan

35 Peraturan Menteri Pendidikan Nasional, No.23, Tahun 2006, Tentang Standar Kompetensi 
perlu adanya penyesuaian, penekanan dan penguatan. Pendidikan Islam sangat erat dengan nilai mempertahankan (bifžn) namun perlu diadakan matari-materi yang memberikan pemahaman terhadap bagaimana berpikir, bersikap, dan bertindak dengan kemjauan dan perkembangan yang terjadi. Adapun upaya-upaya dalam mengembangan kurikulum materi pendidikan agama Islam memperhatikan.

a. Prinsip relevansi, penyesuaian materi dengan situasi dan kondisi lingkunagan kebutuahan peserta didik dan dapat bermanfaat untuknya dimasa yang akan datang.

b. Prinsip fleksibelitas, materi pendidikan Islam dapat menyesuaikan dalam setiap keadaan dengan tetap dalam bingkai pendidikan Islam agar pesrta didik menggapai masa depan yang baik.

c. Prisnsip kontinuitas, materi pendidikan Islam berkesinambungan dan terus menerus dengan memperhatikan segala dinamika perubahan seprti social, jenjang tingkatan, dan kebutuhan peserta didik.

d. Prinsip efisiensi, dalam pengembangan materi pendidikan Islam harus melibatkan setiap stackholder yang terkait (lembaga, para ahli, pengamat, pendidik, peserta didik, dan lain sebagainya) agar tercapai tujuan pendidikan Islam.

e. Prinsip prakatis, mater dapat dipadukan dengan kemajuan teknologiteknologi masa depan. ${ }^{36}$

Materi pembelajaran pendidikan agama Islam harus dapat berkontribusi dalam meningkatkan kualitas skill dalam menghadapi era 4.0. pendidikan agama hari ini apakah berorientasi pada tahap pencegahan atau pertahanan terhadap perubahan-perubahan yang pesat terjadi (era disrupsi). Pendidikan Islam pernah menemukan masa keemasanya, dapat dilihat dari beberapa ilmuan muslim pada masa itu menemukan teknologi yang mengubah peradaban manusia. Jika diperhatikan apa yang dilakukan para ilmuan muslim pada masa tersbut

${ }^{36}$ Haidar Putra, Pendidikan Islam, (Jakarta: Kencana, 2004), hlm 12 
adalah dengan tidak mendikotomi pengatahuan (ilmu agama dan sains) bahkan justru menggali Al-Qur'an sebagai petunjuk sains dan teknologi. ${ }^{37}$ Maka penguatan materi pendidikan agama Islam pada era 4.0 yaitu penguatan ahklak (kepada manuisa atau kepada Tuhan) sehingga tertanam etika yang kuat dalam menyikapi perubahan dan perkembangan. Penguatan muamalah (kemandirian ekonomi dan lain sebagianya) ekonomi yang berdaulat dan menghidupakan ${ }^{38}$ dapat mengurangi tingkat kriminalitas disebuah negara, kesenjangan ekonomi akan melahirkan tindakan-tindakan kejahatan seta dengan perekonomian yang kuat dapat mendukung kegiatan-kegiatan penelitian dalam pendidikan (sains dan teknologi dalam bingkai agama). Maka dalam kajian fikih perlu dikembangan bukan sekedar sebagi norma aturan namun harus dapat merealisasikan sebuah metode dan prinsip dalam mencapai kesejahtraan ekonomi.

3. Metode atau setrategi

Metode pembelajaran yang digunakan harus dapat menyesuiakan dengan keadaan dan kondisi perkembangan anak dan dapat memanfaatkan segala fasilitas pendukung pembelajaran (baik perkembangan taknologi sebagai media pembelajaran dan perkembangan psikologis perkembangan anak sebagai acuan penyesuian metode yang digunakan serta pembelajaran yang bepusat pada guru harus dirubah). Perubahan paradigma belajar dari Teacher centered learning (TCL) ke Student centered learning (SCL), hal ini dilkaukan dalam upaya memberikan atau membuat pelajar menjadi aktif. Apalagi dalam paradigma kalasikal pendidikan agama Islam kerap kali pembelajaran terasa mengikuti sebuah kegiatan pengajian/ceramah total dari pada sebuah aktivitas pembelajaran, dalam padangan klasik siswa hanya menjadi pendegar sejati (pemeblajaran pasif) dan tidak jarang fokus siswa teralihkan bahkan tertidur titengah pembelajaran apalagi

37 Abul Waid, Menguak Fakta Sejarah Penemuan Sains Dan Teknologi Yang Di klaim Barat, (Jogjakarta: Laksana, 2014), hlm 26

${ }^{38}$ Ibid, hlm 32 
ditambah dengan penemptan jam-jam belajar saat para pelajar dekat dengan waktu yang tidak kondusif (jam terakhir).

Pembelajaran yang berpusat pada peserta didik (Student centered learning) adalah upaya agar belajar secara aktif, peranan pendidik yaitu sebagai organisator, mengawasai/mengamati, memfasilitasi, dan mengevaluasi terhadap kegiatan pembelajranya. ${ }^{39}$ Guru harus turut serta memberikan perhatian yang lebih dalam ketrelibatan, inisiatif, dan interaksi social peserta didik. ${ }^{40}$ Adapun beberapa metode yang dapat digunakan dalam pemebelajaran yang berpusat pada peserta didik seperti, Discovery Learning, Problem Based Learning (PBL), Contextual Learning, Project Based Learning (PjBL), Dan Self-Directed Learning.

Metode pembelajaran dengan memanfaatkan teknologi digital dapat berupa metode Bleanded Leraning. Metode ini adalah peroses kegitan belajar mengajar dengan kombinasi dan perpadauan sistem pendidikan konvensional dengan sistem pendidikan digital. ${ }^{41}$ Dengan metode ini pembelajaran dapat dilakukan dimana pun dan kapan pun menggunakan internet, materi telah tersimpan secara online. Pengunaan teknologi digital dan internet sejak dini dan diawasi adalah dalam rangka agar peserta didik dapat melek dengan teknologi sehingga mereka dapat berinovasi dan creative dalam pembelajrannya serta dapat berguna pada masa yang akan datang.

Dalam pendidikan agama Islam terdapat beberpa meteri pemebelajaran berupa hafalan dan pemahaman, praktik serta analisis. Materi berupa hafalan adalah materi yang harus tertanam dalam hatinya sehingga hal tersbut yang akan membentenginya dari perbuatanperbuatan yang bertentangan dengan norma-norma agamanya. Parkatik merupakan bagian dari ajaran Islam sebagai bentuk lanjutan dari pemahaman/haflannya, karena ajaran Islam untuk diamalkan dalam

${ }^{39}$ Tim UIN-SUKA, Sosialisasi Pembelajaran Menjadi Mahasiswa Visioner, (Yogyakarta: UIN-Suka, 2019), hlm 59

40 Zaki Mubarok, Pendidikan Di Era Revolusi Industry 4.0 Dan Problematika Pendidikan Tinggi, (Yogyakarta: Ganding Pustaka, 2018), hlm 115

${ }^{41}$ https:// sevima.com/perbedaan-blended-learning-dan-e-learning/ diakses 30 Mei 2020 
kehidupanya (sebagai aktivitas peribadahan). Analisis adalah bagimana memahami sumber ajaran Islam secara kaffah dan kesesuainnya dengan realita keadaan yang tengah terjadi.

Jika berdasr pada psikologi perkembangan sebagai pendekatan metode yang digunakan dan menjadi acuan penekanan dalam pembelajaranya dapat dipahamai sebagai berikut:

a. Metode hafalan dan tanya jawab pada masa anak-anak (sekolah dasar/ MI), pada masa anak-anak kemampuan menghafal begitu bagus dan cepat, dikatakan oleh ahli bahwa anak-anak ibarat spon yang dapat menghisap air dengan mudah hal ini terbukti dari para ahli Qur'an dan Hadis pada masa lalu telah mampu menghafalnya pada usia anak-anak. contoh Al-Gazali, imam Syafi'i dll. Maka perlu menjadi pertimbangan meteri-materi yang bentuknya hafalan dapat di ajarkan pada usia anak-anak tersbut baik itu hafalan Qur'an, Hadis, ilmu alat (Bahasa Arab dan Bahasa Inggris (bahasa Internasional)) yang berguna untuk masa depanya. Pengusaan berbagai Bahasa akan mampu membuat mereka mamahami informasi-informasi dan pengatahuan baru dari negara lain yang perkembangan dan peradaban pengetahuannya lebih maju. Penguasaan berbagai Bahasa asing pada masa kejayaan Islam adalah menjadi sebuah budaya keilmuan yang membuat mereka dapat memhami dan berinovasi dari pengetahuan yang diperolehnya terbukti dengan adanya muncul budaya menerjemah dikalangan muslim dimulai dari masa Khlifah al-Mnsur, hal inilah yang mengantarkan Islam mencpai kemajuan di berbagai bidang keilmuan dan pengetahuan. ${ }^{42}$

Tanya jawab, adalah sebuah metode pemebalajaran dengan berdiskusi melalui persoses komunikasi dengan bertanya dan menjawab. Metode ini perlu ditanamkan sejak usia dini agar para siswa aktif melontarkan persoalan-persoalan yang tidak diketahui

42 Waid Abul, Menguak Fakta Sejarah Penemuan Sains Dan Teknologi Yang Diklaim Barat, (Jogjakarta: Laksana, 2014), hlm 37-39 
dan dipahaminya, pertanyaan dan jawaban dapat diarahkan oleh pendidik dan melibatkan semua orang didalam kelas ikut serta menjawab untuk siapapun (dari pendidik ke terdidik, dari terdidik ke pendidik, dan dari terdidik ke terdidik). Tanya jawab begitu penting karena hari ini terdidik begitu sulit untuk terbiasa menyampaikan persoalan yang dihadapinya, bahakan tidak mengetahui apa yang mau ditanyakan. Makanya dari sejak dini metode interkasi tanya jawab ini sudah ditanamkan pada terdidik, hal ini dapat dilakukan dengan meberikan mereka tugas membuat pertnyaan dirumah untuk di sampikan ketika kagiatan belajar mengajar berlangsung. Dan bahkan pendidik dapat meberikan tugas lanjutan untuk mereka menemukan jawaban sendiri atas pertanyaan yang telah mereka buat.

b. Metode praktik pada jenjang (SMP/MTs), pada masa ini peserta didik sudah memasuki masa baligh, dimana sudah dibebankan kewajiban atas ajaran-ajaran agama Islam. Namun tentu hal ini sudah dibiasakan sejak dini sebelumnya maka pada masa (SMP/MTs) adalah penekanan dan pemahaman akan tanggung jawabnya sebgai seorang muslim. Dengan penekanan peraktik maka cocok menggunakan metode eksperimental. Metode ini adalah metode pembelajaran dengan menempatakan peserta didik pada aktivitas percobaan dengan membuktikan dan mengalami sendiri apa yang dipelajarainya. ${ }^{43}$

c. Pemabelajaran yang melatih analisis untuk kritis pada jenjang (SMA/MA), pada tahapan ini peserta didik lebih ditekankan pada bagimana merekonstruksi pemahamanya dari bacaan dan pengamatan terhadap materi yang dipelajarinya. Metode yang dapat digunkan berupa problem solving method (pemecahan masalah). Metode ini menekankan pada peserta didik untuk berpikir, mencari data-data, membuka wawasan dan merangsang peserta didik

43 Tedi Priatana, Inovasi Pembelajaran PAI Di Sekolah Pada Era Disruptive Innovation, (Jurnal Tatsqif: Jurnal Pemikiran dan Penelitian Pendidikan, Vol 16, 2018), hlm 28 
berpendapat sehingga akhirnya dapat menerik sebuah kesimpulan sendiri terhadap meteri yang dipelajarinya. ${ }^{44}$

Ketiga pendekatan metode tersbut harus terus dilatih pada setiap jenjang sehingga mereka dapat dengan mudah beradaptasi ketika pada jenjangnya lebih menekankan pada salah satu metode tersbut.

4. Evaluasi

Evaluasi merupakan serangkaian kagiatan pengamatan dan penilaian pada semua hal yang terkait dengan pendidikan terhadap perubahan dan perkembangan yang terjadi dengan berdasar kriteriakriteria yang ditentukan. ${ }^{45}$ Kegiatan evaluasi dilakuakan secara konprehensif terhadap segala aspek yang berkaitan dengan pendidikan/pembelajaran (media, metode, materi, sarana prasarana, dll). Hasil evaluasi kemudian mejadi kajian bersama antar setiap stakeholder yang terkait untuk sama-sama bersinergi dalam menyelesaikan permasalahan-permasalahan yang ditemukan untuk kemudian solusi yang didapat dapat dilaksanakan bersama dan berkelanjutan dari pendidik dan lembaga, masayarakat dan lingkungan, peserta didik dan keluarga, pemangku kebijakan dengan pemerintahnya (karena sumanya adalah bagian dari ekosistem pendidikan). Evaluasi pendidikan agama Islam di era 4.0 berorientasi kepada optimalisasi kemampuan yang diberikan atau ditawarakan oleh perkembangan teknologi untuk menciptakan efektifitas dan inovasi dalam kegitan belajar mengajar.

5. Kompetensi Guru Di Era Revolusi Industry 4.0

Seberapa bagusnya sistem pendidikan atau kurikulum yang telah dibuat kalau kompetensi dari pendidik tidak turut dikembangkan maka akan terjadi hambatan dalam merealisaikan kuirikulum. Pengemabangan kompetensi pendidik harus sejalan dengan dinamika perkembangan

${ }^{44}$ Ibid, hlm 29

45 Zainal Arifin, Konsep dan Model Pengembangan Kurikulum, (Bandung: Remaja Rosdakarya, 2012), hlm 21 
industry 4.0. kompetensi pendidik di era idustri 4.0 yang harus dimiliki dan dikuasai diantaranya yaitu pertama, competence for technological commercialization yaitu kemampuan dalam memahami dan mengusai teknologi serta mampu membut terdidik mempunyai sikap entrepreneurship (kewiwrausahaan) dengan perkembangan teknologi dan berinovasi. Kedua, educational competence, kemampuan pendidik dalam memberikan pembelajaran dengan berbasis internet of thing sebgai basic skill yang harus dimiliki di era industry 4.0. ketiga, competence in globalization adalah kemampuan beradaptasi dengan berbagai budaya dengan dunia tanpa sekat diera global tanpa kehilangan esensi budaya luhur serta kemampuan dalam memecahkan persoalan nasioanal. Keempat, competence in future strategies adalah kompetensi dalam melihat, manganalisis, menilai serta memprediksi peluang-peluang dimasa depan sehingga dapat menentukan strateginya dengan mengikuti penelitian, joint-lecture, joint-resource, dan lain sebagainya. kelima, counselor competence yaitu kemampuan dalam memberikan pemahaman dan solusi terhadap persoalan pelajaran dan psikologi anak yang depresi dan stres akibat tekanan keadaan yang berat dan semakin komlek. ${ }^{46}$

6. Sarana dan Prasarana

Bagian penting juga yaitu sarana dan prasarana harus menjadi perhatian bersama. Tersedianya teknologi pembelajran sebagai sarana prasarana pendukung pembelajaran di era 4.0 untuk menujang peroses pemebelajaran yang efektf dan efisien seperti yang diungkapkan Widodo Winarso. ${ }^{47}$ Ketersedian ruang belajar yang nyaman dan aman akan memberikan efek positif bagi terdidik dalam belajar. Ruang perpustakaan yang memadai dan nyaman sebagai sumber penyedia literasi dari sekolah, kecamatan, kabupaten/kota dan daerah baik literasi yang berbasis kovensional mapuan yang berbasis teknologi (Digital

\footnotetext{
46 Sapti Winarni, Kompetensi Guru Era Revolusi Industry 4.0, (Laman Satelet Post, 2019), https:// satelitpost.com/redaksiana/opini/kompetensi-guru-era-revolusi-industri-4-0 diakses 7 Juni 2013

${ }^{47}$ Widodo Winarso, Dasar Pengembangan Kurikulum Sekolah,(Cirebon: CV. Confident, 2015), hlm 
Library) $^{48}$. Kelompok kegiatan penelitian di sekolah sebgai bagian dari ekstrakurikuler harus dikembangkan guna meningkatkan kepekaan dan daya kritis terhadap persoalan-persoalan yang terjadi dilingkungannya. Dan kesemua itu harus diberikan secara menyeluruh dan merata seperti dikawasan 3T (tertinggal, terdepan dan terluar) karena kamajuan pendidikan merupakan kesatuan.

\section{KESIMPULAN}

Pendidikan agama Islam di era distrupsi harus dapat memberikan kontribusi dalam peningkatan kualitas sumber daya manusia. Orienatasi pendidikan Islam bukan sebatas mata pelajaran keagaman dari bagian kurikulum, namun harus dapat menciptakan intelektual muslim yang dapat memecahakan persoalan masyarakat atau umat. Dalam perubahan dan perkembangan yang terajdai di era 4.0 pendidikan Islam bukan hanya sebagai tindakan preventif tarhadap efek dari sebuah perkembangan era, namun harus menjadi bagian dari perkembangan dan bahakan memotori perubahan dengan sikap keilmuan tanpa dikotomi. Metode pembelajaran pendidikan agama Islam harus dapat dipadukankan dengan perkembangan teknologi. Metode blended leraning adalah peroses kegitan belajar mengajar dengan kombinasi dan perpadauan sistem pendidikan konvensional dengan sistem pendidikan digital. Serta perubahan paradigama belajar dari awalnya pembelajaran terpuasat pada guru diarahkan kepada pemebalajaran terpusat pada siswa (SCL). Dan hasil evaluasi menjadi sbuah tanggung jawab besama untuk diselsaikan secara konperhensif dan berkelanjutan. Pengembangan kompetensi guru sebagai tuntutan dalam pendidikan di era 4.0. dengan lima komptensi yang harus disiapkan yaitu, competence for technological commercialization, educational competence, competence in globalization, competence in future strategies, and counselor competence. Serta kesedian dan kebutuhan sarana dan prasarana yang merata.

${ }^{48}$ Munir, Kurikulum Berbasis Teknologi Informasi dan Komunikasi. (Bandung: Alfabeta. 2009), hlm 111 


\section{DAFTAR PUSTAKA}

Agung, Leo. (2015). Sejarah Kurikulum Sekolah Menengah Di Indonesia, Yogyakarta: Ombak

Aldo Redho Syam. (2019). Guru dan Pengembangan Kurikulum Pendidikan Agama Islam di Era Revolusi Industri 4.0, Jurnal: Tadris vol 14, Nomor 1, 1-18

Arifin, Zainal, (2012), Konsep dan Model Pengembangan Kurikulum, Bandung: Remaja Rosdakarya

Dakir. (2010). Perencanaan dan Pengembangan Kurikulum. Jakarta: Rineka Cipta

Dedi G Sanusi (19 Maret 2019). Hasil Surve Pustekom 60 Persen Guru Di Indonesia Gagap Teknologi. Jejakrekam, diakses 21 Oktober 2019. http://jejakrekam.com/2019/03/19/hasilsurvei-pustekkom-60-persen-guru-di-indonesia-gagapteknologi-informasi/

Dewantoro, M Hajar. (2003). Pengembangan Kurikulum Pendidiakan Agama Islam, Jurnal: JPI FIAI Jurusan Tarbiyah, Vol 9, 49-57

Idi, Abdullah. (2013). Pengamabangan Kurikulum Teori dan Praktik, Yogyakarta: Ar-Ruzz Media

Jon Darmawan (27 November 2018). Menjadi Guru Era Pendidikan 4.0. TribunNews, diakses 14 Juni 2020. https://www.google.com/amp/s/aceh. tribunnews.com/amp/2018/11/27/ menjadi-guru-era-pendidikan-40

Keputusan Menteri Agama Republik Indonesia Nomor 183 Tahun 2019 tentang Kurikulum PAI dan Bahasa Arab pada Madrasah

Mubarok, Zaki. (2018) Pendidikan Di Era Revolusi Industry 4.0 Dan Problematika Pendidikan Tinggi, Yogyakarta: Ganding Pustaka

Muhaimin. (2008). Paradigma Pendidikan Islam: Upaya Mengefektifkan Pendidikan Agama Islam Di Sekolah, Bandung: PT Remaja Rosdakarya

Muhtadin. (2016). Pendidikan Agama Islam Pada Perguruan Tinggi, Jakarta: Mandala Nasioanal

Munir. (2010). Kurikulum Berbasis Teknologi Informasi dan Komunikasi, Bandung: CV Alfabeta

Pratt, David. (1980). Curriculum Design And Development, USA: Harcourt Brace Javanovich Publisher

Risdianto,Eko. (2019). Analsisis Pendidikan Indonesia di Era Revolusi Industri 4.0. Bengkulu: Universitas Bengkulu

Sapti Winarni (7 Maret 2019). Kompetensi Guru Era Revolusi Industry 4.0.

Satelitpost, diakses 7 Juni 2019.

https:/ / satelitpost.com/redaksiana/opini/kompetensi-guru-era-revolusiindustri-4-0

Savitri, Astrid. (2019). Revolusi Industri 4.0: Mengubah Tatntangan Menjadi Peluang di Era Disrupsi 4.0. Yogyakarta: Genesis 
Sukmadinata, Nana Syaodih (2014), Pengembangan Kurikulum Teori dan Praktek, Bandung: Remaja Rosdakarya

Susilo, Muhammad Joko. (2008). Kurikulum Tingkat Satuan Pendidikan Manajeman Pelaksanaan Dan Kesiapan Sekolah Menyonsongnya, Yogyakarta: Pustaka Belajar

Sutrisno, (2008), Pendidikan Islam Yang Menghidupkan, Yogyakarta: Kota Kembang

Tafsir, Ahmad, (2014). Cakrawala Pemikiran Pendidikan Islam. Bandung: Mimbar Pustaka

Tim UIN-SUKA, (2019), Sosialisasai Pembelajran Menjadi Mahasiswa Visioner, Yogyakarta: UIN-Suka

Waid, Abul, (2014), Menguak Fakta Sejarah Penemuan Sains Dan Teknologi Yang Diklaim Barat, Jogjakarta: Laksana

Winarso, Widodo, (2015), Dasar Pengemabangan Kurikulum Sekolah, Cirebon: CV. Confident

Sevima (9 April 2019). Revolusi Industri 4.0 Yang Sudah Di Depan Mata. Sevima.com, diakses pada 14 Juni 2020. https://sevima.com/revolusi-industri4-0-yang-sudah-di-depan-mata/

(7 agustus 2018). Perbedaan blended leraning dan e-learning. Sevima.com, diakses 30 Mei 2020. https://sevima.com/perbedaan-blended-learning-dan-elearning/

Siti Umaiyah (23 April 2019). Era Industri 4.0 Menjadi Tantangan Bagi Pendidikan Agama. TribunNews, diakses $20 \quad$ Mei 2020. https://jogja.tribunnews.com/2019/04/23/era-industri-40-menjadi-tantanganbagi-pendidikan-agama? 